DIW BERLIN

Discussion

Papers

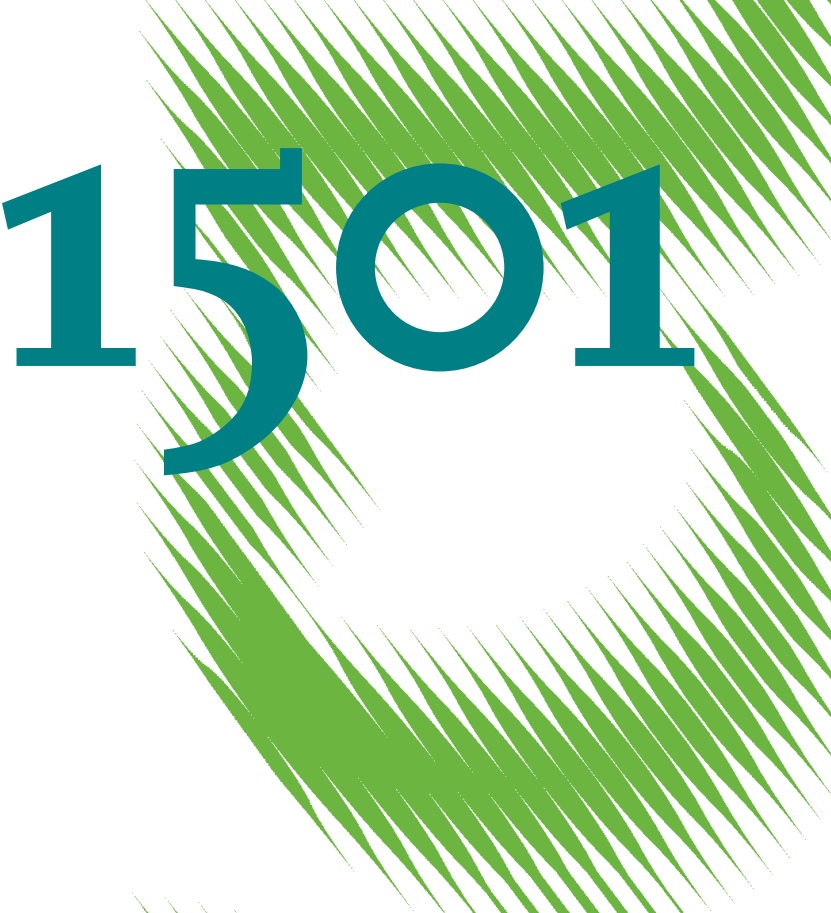

The Power of Opinion:

More Evidence of a GIPS-Markup in Sovereign Ratings During the Euro Crisis 
Opinions expressed in this paper are those of the author(s) and do not necessarily reflect views of the institute.

IMPRESSUM

(C) DIW Berlin, 2015

DIW Berlin

German Institute for Economic Research

Mohrenstr. 58

10117 Berlin

Tel. +49 (30) $89789-0$

Fax +49 (30) $89789-200$

http://www.diw.de

ISSN electronic edition 1619-4535

Papers can be downloaded free of charge from the DIW Berlin website:

http://www.diw.de/discussionpapers

Discussion Papers of DIW Berlin are indexed in RePEc and SSRN:

http://ideas.repec.org/s/diw/diwwpp.html

http://www.ssrn.com/link/DIW-Berlin-German-Inst-Econ-Res.html 


\title{
The Power of Opinion: More Evidence of a GIPS-Markup in Sovereign Ratings During the Euro Crisis
}

\author{
Steffen Nauhaus*
}

August 2015

\begin{abstract}
This paper examines whether the Big Three credit rating agencies actually played as active a role in the Euro Crisis as previously asserted. On the basis of panel data methods for a set of 11 EMU countries, the analysis reveals significant evidence for an arbitrary markup on the GIPS group of countries across agencies. This markup, which ranges from 1.5 notches for Moody's to 2.2 notches for S\&P, suggests that GIPS countries were treated worse than other EMU members since the start of the Eurozone crisis in 2009, irrespective of economic and institutional fundamentals. A subsequent analysis of the markup's effect on yield spreads shows that this markup had significant effects on financial markets, leading to risk premiums for these countries of up to 1.6 points.
\end{abstract}

Keywords: Rating agencies, Sovereign ratings, Eurozone, Euro crisis, Debt crisis

JEL Classification: G24, H63, F34

* Steffen Nauhaus was a guest researcher at the DIW Berlin from January to August 2014, through his alma mater Stockholm School of Economics (steffen.nauhaus@alumni.hhs.se). The author is indebted to Dirk Ulbricht, Bo Becker, Ferdinand Fichtner, Dorothea Schäfer, Adam Lederer, Claudia Lambert, Franziska Bremus, Aljaz Kuncic, Philipp König, Anais Lousolo, Örjan Sjöberg and Yoichi Sugita for valuable suggestions and advice. Gratitude is expressed furthermore to the DIW Berlin and the participants of the DIW lunchtime seminar on May 12, 2014. 


\section{Introduction}

Rating agencies came under intensive scrutiny following the 2007/08 global financial crisis. Stemming from a number of, in hindsight, apparent and considerable shortcomings, particularly with regard to structured products, criticism emerged on both sides of the Atlantic. The ongoing sovereign debt crisis in Europe saw this debate reopened, challenging the role and responsibility of rating agencies in the global financial system. The Big Three rating agencies - Standard \& Poor's, Moody's, and Fitch - had come under considerable pressure for what was perceived as unfair and immoderate sovereign rating downgrades; especially from within the EU. In the eyes of many, sharp downgrades of debt issued by peripheral Eurozone countries put excessive pressure on interest rates, thereby raising borrowing costs and worsening the crisis.

A study by Gärtner, Griesbach, and Jung (2011) finds some concrete evidence in support of such critiques. Studying the ratings of Fitch, the authors find that the agency used a significant markup on the so called GIPS group of countries; Greece, Ireland, Portugal and Spain. This study, in turn, investigates whether these results are extendable to the other two, significantly larger, agencies Moody's and Standard \& Poor's (S\&P). With a combined market share of eighty percent, Moody's and S\&P exert considerable influence on financial markets, potentially making them a much larger threat to weak debtors than Fitch Ratings. Given the importance of the Big Three for financial markets and financial stability, close scrutiny should be paid to their actions, especially during crises.

By and large following the methods used by Gärtner et al. (2011), this paper assesses whether or not credit ratings of GIPS countries during the crisis by the Big Three can be justified on the basis of economic and institutional fundamentals. Subsequently, a decomposition of credit ratings into explained and unexplained components is used to assess how financial markets take each component into account. Using panel methods on a subset of 11 out of 17 EMU members, the results suggest that all three rating agencies used a significant markup on the four GIPS counties, although to a different extent. Moreover, all markups are shown to exert a significant negative effect on yield spreads, implying that all components of these ratings - including the idiosyncratic markup - affect market participants. These results thus confirm the previous findings of Gärtner et al.

The paper is structured as follows. The following section discusses the market for sovereign ratings and CRAs' behavior during the crisis. Section 3 describes the data. Subsequently, section 4 assesses the extent that rating agencies used a markup on GIPS countries and section 5 tests this markup's effect on yield spreads. Section 6 concludes.

\section{Sovereign credit rating markets}

Markets for sovereign ratings are of a somewhat distinct nature. Unlike private bond markets, they are, as Mellios and Paget-Blanc (2006, p. 361) note, "characterized by the absence of a bankruptcy code". Where a private borrower's assets are seizable in case of default, lenders have no access to a sovereign's domestic assets, implying a more complex incentive structure on the side of borrowers (see e.g. Clark \& Zenaidi, 1999). Actual instances of sovereign default are quite rare. Moreover, although highly consequential to market participants, the ratings of sovereign debt are relatively unimportant to the agencies themselves in terms of revenue (Becker, 2011). These factors hint towards an explanation of why only a handful of agencies has set foot in the market for sovereign ratings to a notable extent, 
despite the tremendous growth in sovereign bond markets. Fuchs and Gehring (2013), for example, identify only six rating agencies other than the Big Three that rate bonds of at least 25 sovereign issuers.

Despite the importance given to CRAs through financial regulation (see e.g. White, 2010), criticism by policy makers about the Big Three has been common throughout financial crises. This is the case particularly in the course of the European sovereign debt crisis (see e.g. Fuchs \& Gehring, 2014). Ratings of Eurozone countries did, in fact, deteriorate notably in the five years following the start of Financial Crisis. As evident from figure 2.1, at least seven out of seventeen EMU countries received the highest rating across agencies in 2007, and none were rated below investment grade. Just five years later, only six, five and four countries retained AAA status by Fitch, Moody's and S\&P, respectively. Five countries had either already fallen below the junk-threshold (BBB-/Baa3) or were rated in close vicinity to it.
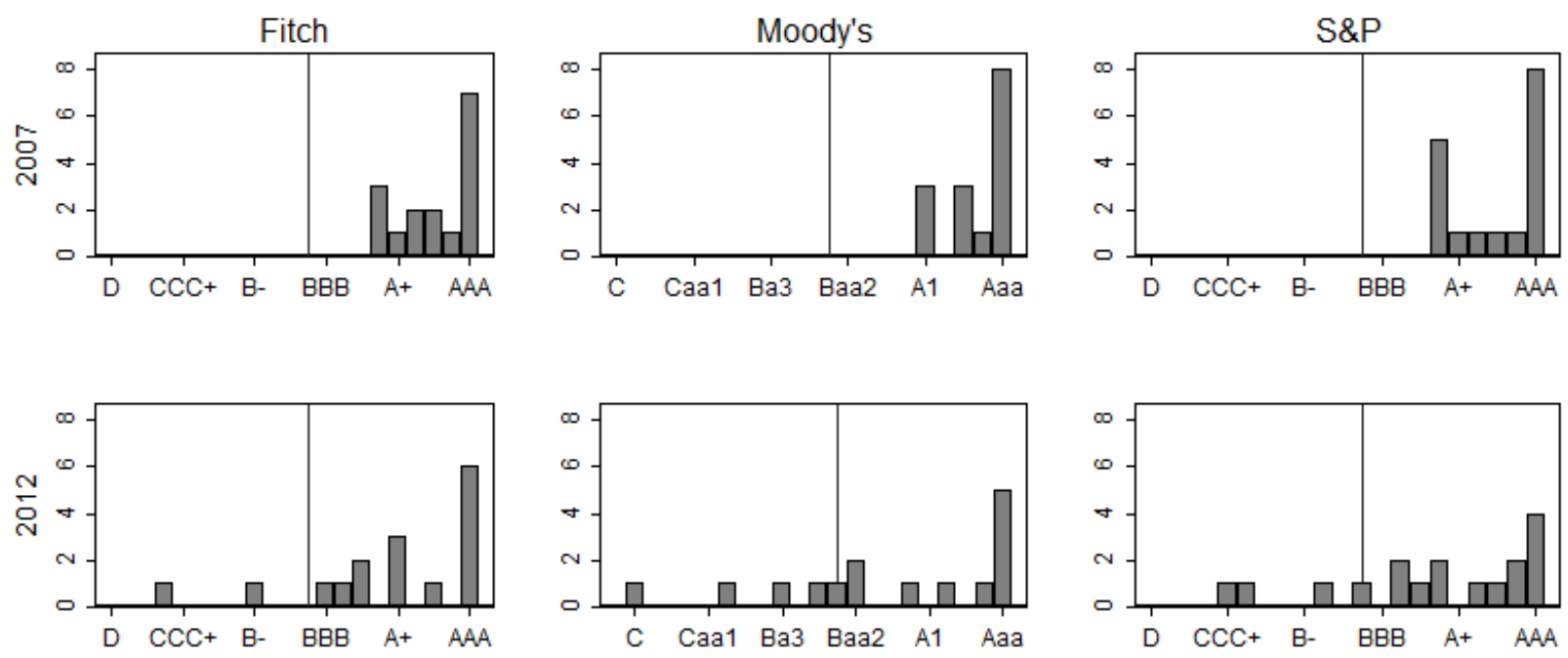

Figure 2.1 Frequency distribution of sovereign ratings in 2007 and 2012 Data source: Bloomberg Terminal

Large and unexpected downgrades tend to have stronger implications for ratees than modest downgrades. Between the three agencies, only S\&P appears to have avoided large downgrades to some extent (figure 2.2), although the agency downgraded more frequently than its competitors. All in all, S\&P announced 45 downgrades between 2007 and 2012, of which four exceeded two notches but none were larger than three notches. Of the Big Three, Moody's made the largest downgrades, on average, with 10 out of 38 downgrades exceeding two notches. In two cases Moody's moved ratings downward by four notches and, in one case, by five notches. In June 2010, Moody's lowered Greece's rating by four notches, from A3 to Ba1. Although the event was preceded by a negative outlook change, markets were taken by surprise by its severity, moving Greece below investment grade and raising risk weights five-fold. A surge in yields ensued (De Haan \& Amtenbrink, 2011). Fitch was generally in between the two extremes, announcing fewer downgrades in total than S\&P but also fewer extreme downgrades than Moody's. Only its July 2011 downgrade of Greece exceeded 3 notches. 

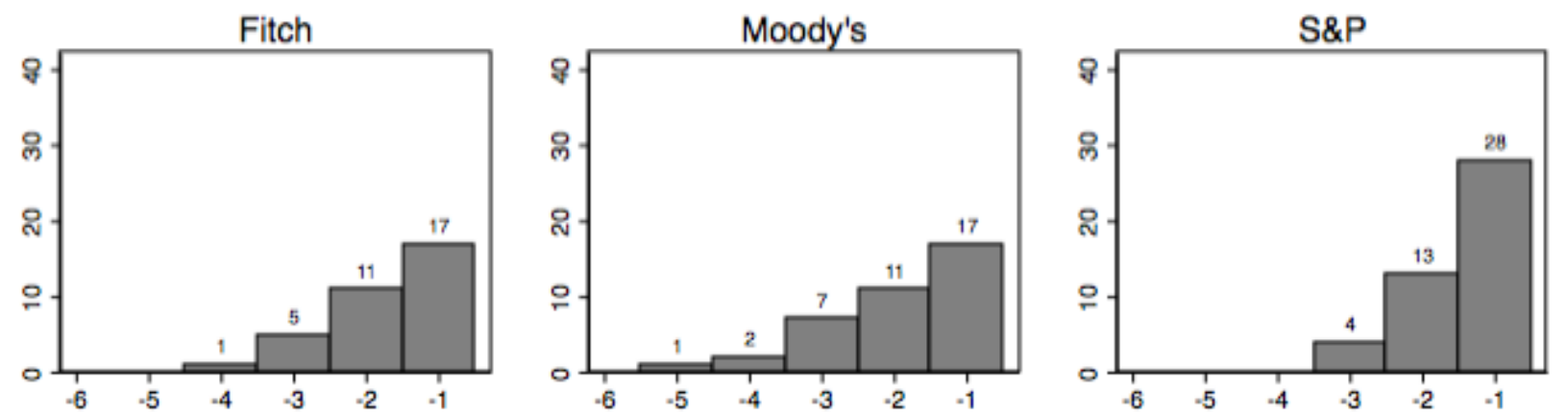

Figure 2.2 Size and frequency of downgrades between 2007 and 2012 Data source: Bloomberg Terminal

However, these developments do not necessarily imply biases on behalf of rating agencies per se. Given the "through-the-cycle" methodology of CRAs, credit ratings should be unaffected by fluctuations in the business cycle (Alsakka \& ap Gwilym, 2010). The trends may instead be attributable to a severe deterioration in the economic climate of peripheral Eurozone countries. Whether or not they were justified thus requires an evaluation of the economic developments in the Eurozone with respect to their effect on credit ratings.

\section{Data}

The empirical analysis uses data for 11 out of the 17 current members of the EMU. Due to the absence of data on long-term bond yields for Cyprus, Estonia, Luxembourg, Malta, Slovenia and the Slovak Republic, these countries are excluded from the analysis ${ }^{1}$. The time horizon for the analysis spans from 1999 to 2013, which is adopted from the underlying study of Gärtner et al. (2011). A notable issue in choosing a longer time horizon would be the introduction of the common currency in 1999, which poses a structural break that is best avoided. Moreover, several data series used in the analysis do not go back much further than 1999. A longer data period would thus require a different choice of variables for the analysis, which would rule the results incomparable to Gärtner et al.

\begin{tabular}{lccccccccccc}
\hline S\&P and Fitch & $\mathrm{AAA}$ & $\mathrm{AA}+$ & $\mathrm{AA}$ & $\mathrm{AA}-$ & $\mathrm{A}+$ & $\mathrm{A}$ & $\mathrm{A}-$ & $\mathrm{BBB}+$ & $\mathrm{BBB}$ & $\mathrm{BBB}-$ \\
Moody's & $\mathrm{Aaa}$ & $\mathrm{Aa} 1$ & $\mathrm{Aa} 2$ & $\mathrm{Aa} 3$ & $\mathrm{~A} 1$ & $\mathrm{~A} 2$ & $\mathrm{~A} 3$ & $\mathrm{Baa} 1$ & $\mathrm{Baa} 2$ & $\mathrm{Baa} 3$ \\
Transformation & 21 & 20 & 19 & 18 & 17 & 16 & 15 & 14 & 13 & 12 \\
\hline S\&P and Fitch & $\mathrm{BB}+$ & $\mathrm{BB}$ & $\mathrm{BB}-$ & $\mathrm{B}+$ & $\mathrm{B}$ & $\mathrm{B}-$ & $\mathrm{CCC}+$ & $\mathrm{CCC}$ & $\mathrm{CCC}-$ & $\mathrm{CC}$ & $\mathrm{SD} / \mathrm{D}$ \\
Moody's & $\mathrm{Ba} 1$ & $\mathrm{Ba} 2$ & $\mathrm{Ba} 3$ & $\mathrm{~B} 1$ & $\mathrm{~B} 2$ & $\mathrm{~B} 3$ & $\mathrm{Caa} 1$ & $\mathrm{Caa} 2$ & $\mathrm{Caa} 3$ & $\mathrm{Ca}$ & $\mathrm{C}$ \\
Transformation & 11 & 10 & 9 & 8 & 7 & 6 & 5 & 4 & 3 & 2 & 1 \\
\hline
\end{tabular}

\section{Table 3.1 Linear transformation of rating scale}

Data on rating announcements were obtained through Bloomberg Terminal. Following Afonso, Furceri, and Gomes (2012, p. 34), the ratings were then transformed linearly to a 21-point scale, with 21 the

\footnotetext{
${ }^{1}$ Data for benchmark bond yields of these countries generally does not go back as far 1999, as instruments with a sufficient (residual) maturity are not available. See e.g. Economic and Financial Committee (2004, pp. 5 ff.) as well as notes in the ECB's Statistical Data Warehouse, series IRS.
} 


\begin{tabular}{lrrrrr}
\hline & Mean & Std. dev. & Min. & Max. & Obs. \\
\hline Fitch & 19.152 & 3.123 & 4 & 21 & 165 \\
Moody's & 19.109 & 3.553 & 1 & 21 & 165 \\
S\&P & 19.036 & 3.193 & 2 & 21 & 165 \\
GDP per capita & 10.137 & 0.279 & 9.542 & 10.621 & 165 \\
GDP growth & 1.794 & 2.368 & -6.143 & 10.391 & 165 \\
Inflation & 2.201 & 0.864 & -0.947 & 5.024 & 165 \\
Primary balance & 0.547 & 3.797 & -16.333 & 7.967 & 165 \\
Gross debt & 75.358 & 29.296 & 24.600 & 176.200 & 165 \\
Gross debt sq & 6531.888 & 5187.659 & 605.16 & 31046.439 & 165 \\
Current account & -0.720 & 5.846 & -16.651 & 8.364 & 165 \\
Trade openness & 0.906 & 0.407 & 0.467 & 1.854 & 165 \\
Population & 16.681 & 1.006 & 15.139 & 18.229 & 165 \\
Government effectiveness & 1.444 & 0.524 & 0.214 & 2.264 & 165 \\
Bond yield (eoy) & 4.566 & 3.044 & 1.299 & 37.473 & 165 \\
\hline
\end{tabular}

This table depicts summary statistics for the variables employed in the subsequent sections. Gross debt, primary balance, current account and trade openness are measured in percent of GDP, GDP per capita and population in natural logs. All percentages are in units of percentage points. Bond yields are measured as end-of-year (eoy).

\section{Table 3.2 Descriptive Statistics}

highest (AAA) and 1 the lowest (D), as depicted in table 3.1. All models use end-of-year ratings.

Ten explanatory variables are used in the empirical analysis. A description of the employed regressors, including definitions, adjustments and sources, can be found in table A.1 in appendix A.

The inclusion of the first five explanatory variables (table 3.2) follows from Gärtner et al. (2011). A squared term for debt is included to control for non-linearities in the treatment of countries' debt-toGDP ratios. Current account balance, trade openness and population are included based on theoretical considerations in the literature as well as information in the rating manuals of the Big Three. Large current account deficits are an indication that a country relies excessively on funds from abroad (Cantor \& Packer, 1996). International trade is shown to have positive impacts on economic growth, access to capital markets as well as credit ratings (Biglaiser \& Staats, 2012). Population is included as a measure of the relative size of a country. As noted by Fuchs and Gehring (2013), large countries tend to be less affected by external shocks, as they are typically more diversified than smaller countries. With regard to institutional factors, the Worldwide Governance Indicators of Kaufmann, Kraay, and Mastruzzi (2011) are used previously most notably by Biglaiser and Staats (2012), who also provide a thorough theoretical foundation for their inclusion. Only one variable is included, since the individual WGI variables are highly correlated. Government Effectiveness was selected in correspondence to CRAs' rating manuals, who unanimously state the importance of governments' effectiveness in responding to shocks (see also Biglaiser \& Staats, 2012).

\section{The determinants of sovereign ratings during the Euro crisis}

Due to the secrecy inherent in the rating agencies' business model, the information actually contained in a credit rating is opaque. Hence, information, including the exact set of variables used to determine ratings, the weight applied to each factor, and the functional form of the rating scale, are a priori 
unknown. Studies of rating determinants thus seek to explain ratings $R$ issued by a respective rating agency $a$ for the debt of country $i$ at time $t$ as a function of some economic, political and institutional or fixed factors $X$, such that

$$
R_{a, i, t}=f\left(X_{i, t}\right)
$$

where both the factors contained in $X$ as well as the functional form of $f\left(X_{i, t}\right)$ are unknown. Having selected a set of explanatory variables, the effect of each is assessed through a panel regression of the form

$$
R_{a, i, t}=\alpha+\beta^{I} X_{i, t}+\epsilon_{a, i, t}
$$

where $R$ is a vector of sovereign credit ratings and $X$ a vector of rating determinants with the corresponding beta coefficients contained in vector $\beta$. The model is linear, following the consensus in the literature that uses the same representation of credit ratings. Afonso, Gomes, and Rother (2007, p. 11) e.g. note that "a linear representation is quite adherent to the data". To test for idiosyncratic treatment of the GIPS countries during crisis, equation (4.2) is augmented with dummy variables, such that

$$
R_{a, i, t}=\alpha+\beta^{I} X_{i, t}+\delta C R I S I S_{i, t}+\lambda G I P S_{i, t}+\gamma\left(G I P S_{i, t} * C R I S I S_{i, t}\right)+\epsilon_{a, i, t}
$$

Given strong evidence of heteroskedasticity, employing a Breusch-Pagan/Cook-Weisberg test, all models are estimated using panel-level heteroskedasticity-corrected standard errors. The baseline model uses Beck and Katz (1996) panel-corrected standard error (PCSE) parameter estimates, all other models use standard errors clustered at the country-level. There is no evidence of autocorrelation in the dependent variable, using the Wooldridge (2010) test for autocorrelation in panel data.

\subsection{Results: Baseline model}

Table 4.1 presents the baseline model and, for comparison, a model without dummy variables for the three agencies. In essence, the dummy variables represent a systematic error term measuring idiosyncratic treatment by the Big Three of GIPS countries during the crisis. Similar to Gärtner et al. (2011), the inclusion of these dummies adds additional explanatory power to the models. The $\mathrm{R}$-squared increases by one to two points across the three agencies ${ }^{2}$. Although not all variables are significant in every regression, each is significant in at least one. Inflation is significant only in the specification with dummies for S\&P. This is not surprising, however, given that all countries share the same currency. Overall, the signs of all but one coefficient point in the intuitively expected direction ${ }^{3}$.

\footnotetext{
${ }^{2}$ Information criteria such as the Akaike (AIC) or Schwarz (BIC) criteria are not readily available for the clustered models used in the analysis, as their generalization to the latter case is not straight forward.

${ }^{3}$ The sign of the current account balance picks up a negative correlation of the capital account and the countries' rating. GIPS countries experienced particularly large capital outflows since the onset of the crisis. The resulting capital account deficits cause a surplus in the current account, resulting in a negative sign for the coefficient.
} 

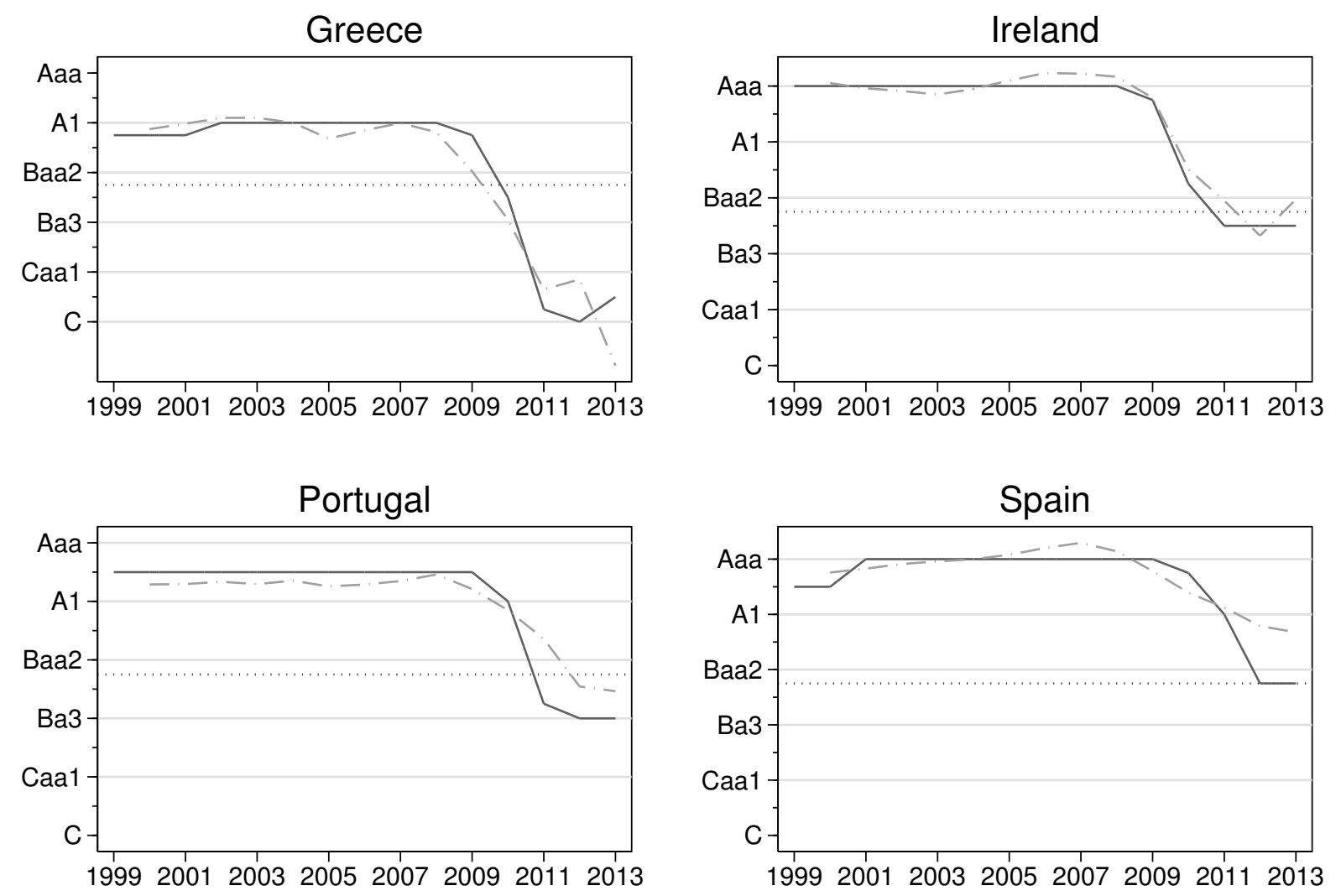

Figure 4.1 Predicted (dashed line) and actual ratings (solid line) of Moody's, GIPS countries

The relevance of adding a markup for GIPS countries is visualized by figure 4.1, which compares the observed credit ratings of Moody's for the GIPS with a linear prediction based only on fundamentals. Results for all agencies and a wider set of countries, including both crisis and non-crisis countries, are provided in appendix A in figures A.1, A.2 and A.3. As indicated by the vertical difference between the two lines, actual credit ratings of GIPS countries tend to be notably lower than fundamentals would predict them to be, since at least 2010. On average, ratings were around one notch lower than predicted across countries and agencies from 2009 to 2013.

The fact that ratings tended to be higher than predicted in 2009 for crisis countries, while substantially lower in the following years for Portugal, Ireland and Spain suggests that the agencies may have overcompensated to some extent. Credit ratings of Spain and Portugal were thus on average almost two notches lower than predicted from 2010 onwards, and Greece's over one notch. However, for the two most recent years in the sample this pattern remains apparent for only Portugal and Spain, whose ratings remain between one and four notches lower than predicted. Ireland's observed rating has been much closer to its predicted value. Greece is the single country that received a rating notably higher than predicted: Over one notch higher on average since 2012 and between three and more than four notches in 2013 only. 


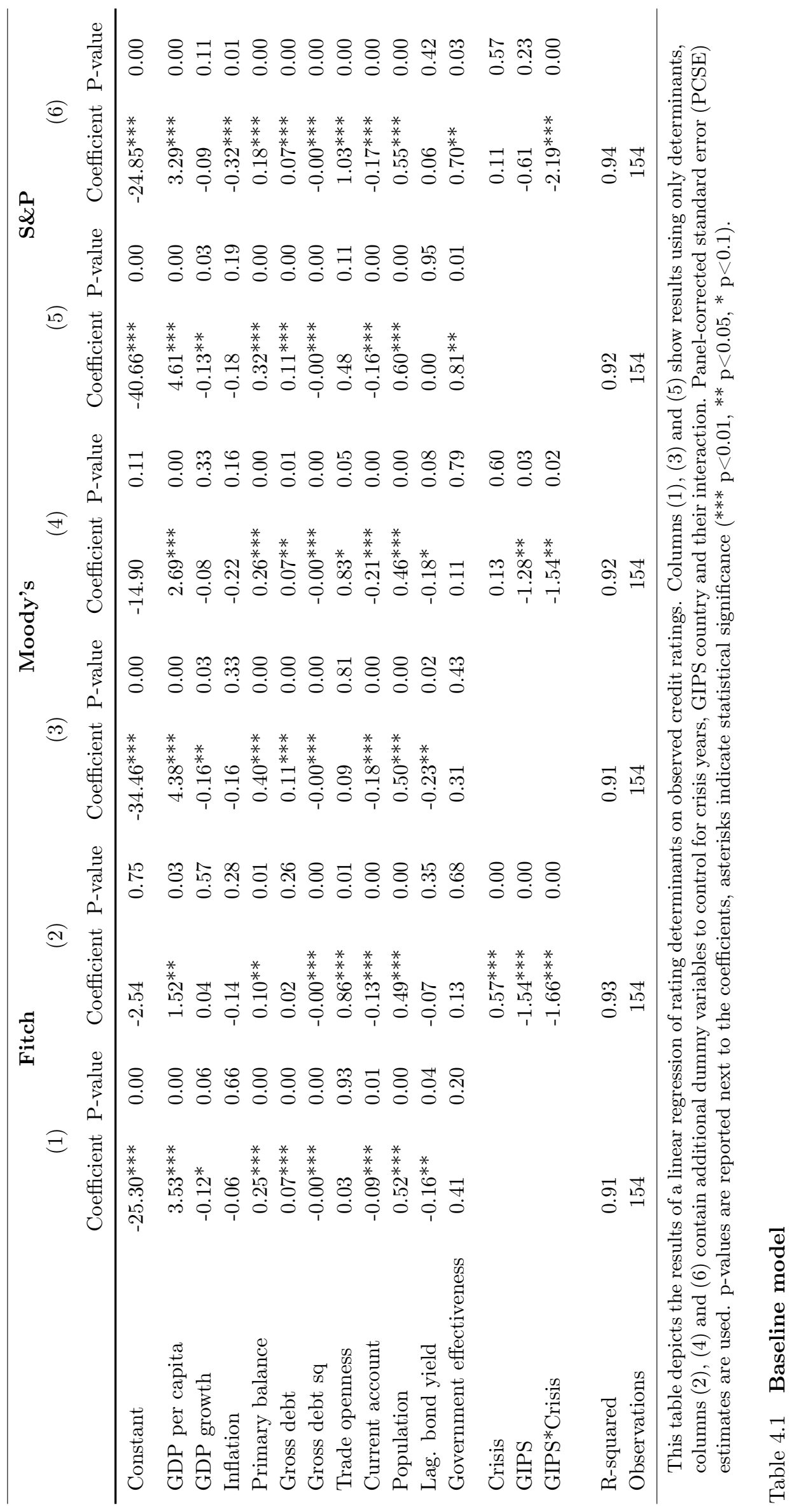




\subsubsection{Robustness checks}

One general concern in country panels is the potential existence of unobserved heterogeneity. For sovereign ratings, this is previously noted e.g. by Biglaiser and Staats (2012). As a robustness check to unobserved heterogeneity at the country level, table 4.2 presents the results of a fixed-effects regression with clustered standard errors. Almost all previously significant coefficients become insignificant. Moreover, all three models are characterized by a much lower fit than in the baseline model. The markup on GIPS countries during the crisis is reduced in size and significance for all agencies, but remains significant at the 1-percent level for Fitch and S\&P. Moody's is significant at the 10-percent level.

\begin{tabular}{lcccccc}
\hline & \multicolumn{2}{c}{ Fitch } & \multicolumn{2}{c}{ Moody's } & \multicolumn{2}{c}{ S\&P } \\
& Coefficient & P-Value & Coefficient & P-Value & Coefficient & P-Value \\
\hline Constant & -8.20 & 0.92 & 186.50 & 0.10 & 33.93 & 0.68 \\
GDP per capita & 2.77 & 0.35 & $6.85^{*}$ & 0.09 & $6.94^{* *}$ & 0.05 \\
GDP growth & 0.03 & 0.83 & -0.17 & 0.38 & -0.13 & 0.23 \\
Inflation & -0.19 & 0.50 & -0.31 & 0.33 & -0.36 & 0.20 \\
Primary balance & 0.07 & 0.33 & $0.22^{*}$ & 0.05 & 0.13 & 0.13 \\
Gross debt & -0.01 & 0.79 & 0.06 & 0.33 & 0.05 & 0.27 \\
Gross debt sq & $-0.00^{* *}$ & 0.02 & $-0.00^{* * *}$ & 0.00 & $-0.00^{* * *}$ & 0.00 \\
Trade openness & 1.50 & 0.54 & -0.36 & 0.91 & 0.67 & 0.80 \\
Current account & -0.08 & 0.15 & $-0.15^{* *}$ & 0.04 & -0.11 & 0.15 \\
Population & 0.05 & 0.99 & $-14.01^{*}$ & 0.09 & -5.12 & 0.38 \\
Lag. bond yield & -0.08 & 0.20 & $-0.16^{* *}$ & 0.04 & 0.09 & 0.27 \\
Government effectiveness & 0.80 & 0.26 & 0.01 & 0.99 & 0.92 & 0.28 \\
Crisis & $0.72^{* *}$ & 0.03 & 0.51 & 0.25 & 0.37 & 0.31 \\
GIPS*Crisis & $-1.44^{* * *}$ & 0.01 & $-1.12^{*}$ & 0.07 & $-1.86^{* * *}$ & 0.01 \\
R-squared & & & & & & 0.88 \\
Observations & 0.87 & & 0.88 & & 154 \\
\hline
\end{tabular}

This table presents the results of a fixed-effect regression of rating determinants and dummy variables on credit ratings for Fitch, Moody's and S\&P. The GIPS-dummy is excluded due to multicollinearity. Standard errors are clustered on country level. p-values are reported next to the coefficients, asterisks indicate statistical significance $\left(* * * \mathrm{p}<0.01, * * \mathrm{p}<0.05,{ }^{*} \mathrm{p}<0.1\right)$.

\section{Table 4.2 Robustness check controlling for unobserved heterogeneity}

Another potential issue, found e.g. in Mellios and Paget-Blanc (2006), relates to the functional form of the rating scale. Since the latter is essentially unknown, a linear representation is commonly used as a simple approximation. However, there are grounds to question the equidistant functional form of the rating scale on. The one-notch difference between an AA+ and an AA rating may differ substantially from that between a BBB- and a BB + rating, for example, in light of the change in risk-weights under the Basel capital framework (see Bank for International Settlement, 2013). To allow for non-linearities in the rating scale, table 4.3 presents the results of a random-effects ordered logit model for panel data. The coefficients represent the marginal effects at means. Complete results with cutoff points can be found in appendix A. 
Although the R-squared of the previous models cannot be compared directly to the pseudo R-squared of a logit regression, the latter performs notably worse than the baseline model. Like the results of the fixed-effects regression, most of the coefficients turn insignificant. The GIPS-crisis markup is reduced further in size and significance, compared to the fixed effects model, to the point that it is only significant, at the 10-percent level, for S\&P. Instead, the markup for GIPS countries over the entire sample horizon is substantially larger in size for Fitch and Moody's, however. This would suggest that rating agencies assigned systematically lower ratings for GIPS countries even before the onset of the Eurozone crisis. However, the size of the GIPS dummy, particularly for Fitch, appears unrealistic.

\begin{tabular}{lcclccc}
\hline & \multicolumn{2}{c}{ Fitch } & \multicolumn{2}{c}{ Moody's } & \multicolumn{2}{c}{ S\&P } \\
& Coefficient & P-Value & Coefficient & P-Value & Coefficient & P-Value \\
\hline Constant & & & & & & \\
GDP per capita & 4.40 & 0.45 & $16.09^{*}$ & 0.08 & $18.25^{* *}$ & 0.04 \\
GDP growth & 0.44 & 0.49 & -0.32 & 0.59 & $-0.56^{* *}$ & 0.02 \\
Inflation & -0.28 & 0.79 & $-1.34^{* *}$ & 0.05 & -1.38 & 0.34 \\
Primary balance & 0.02 & 0.92 & $0.74^{* *}$ & 0.03 & $0.69^{* * *}$ & 0.01 \\
Gross debt & -0.33 & 0.16 & $-0.34^{* * *}$ & 0.00 & $-0.29^{*}$ & 0.05 \\
Gross debt sq & 0.00 & 0.54 & 0.00 & 0.18 & 0.00 & 0.70 \\
Trade openness & -1.67 & 0.50 & -5.82 & 0.24 & 1.95 & 0.67 \\
Current account & $-0.34^{*}$ & 0.06 & $-0.48^{* * *}$ & 0.00 & $-0.78^{* * *}$ & 0.00 \\
Population & -0.13 & 0.93 & -0.80 & 0.61 & $4.18^{* *}$ & 0.02 \\
Lag. bond yield & 0.03 & 0.87 & -0.03 & 0.86 & $0.36^{*}$ & 0.08 \\
Government effectiveness & 2.40 & 0.31 & $2.85^{* * *}$ & 0.01 & $7.60^{*}$ & 0.05 \\
Crisis & 1.92 & 0.16 & -0.38 & 0.49 & $-1.39^{* *}$ & 0.02 \\
GIPS & $-8.46^{* * *}$ & 0.00 & $-5.90^{*}$ & 0.08 & -4.23 & 0.20 \\
GIPS*Crisis & -1.59 & 0.11 & 0.56 & 0.52 & $-2.09^{*}$ & 0.06 \\
& & & & & & \\
Pseudo R-squared & 0.55 & & 0.55 & & 0.59 & \\
Observations & 154 & & 154 & & 154 & \\
\hline
\end{tabular}

This table presents the results of a random-effects ordered logit regression of rating determinants and dummy variables on credit ratings for Fitch, Moody's and S\&P. The coefficients represent marginal effects at means (cutoff points can be found in appendix A). Standard errors are clustered on country level. p-values are reported next to the coefficients, asterisks indicate statistical significance $\left(* * * \mathrm{p}<0.01,{ }^{* *} \mathrm{p}<0.05,{ }^{*} \mathrm{p}<0.1\right)$.

\section{Table 4.3 Robustness check for non-linear rating scale}

Overall, the baseline model and, in particular, the coefficient of the GIPS-crisis dummy are robust in the majority of cases. While the results of the ordered logit model vary substantially between the three agencies, suggesting an inconsistent estimation method, the results of the fixed-effect regression confirm the underlying hypothesis of an unequal treatment. Given the the consensus in the literature, which predominantly uses a linear representation of credit ratings, as well as some technical considerations ${ }^{4}$, the linear PCSE-model is therefore used as the baseline model.

\footnotetext{
${ }^{4}$ See Gärtner et al. (2011, p. 296)
} 


\section{Decomposing sovereign ratings' effect on yield spreads}

While the results of the previous section show that rating agencies actually did use a markup on the peripheral crisis countries, it remains to be shown that this markup influenced borrowing costs of these governments. Previous studies show a significant effect of credit ratings on yields spreads under various set-ups. All, by and large, follow Cantor and Packer (1996), who appear to be the first to stress this relationship. As table 5.1 shows, the same observation can be made for this particular sample: Rating announcements are negatively related to changes in yield spreads.

\begin{tabular}{lcccccc}
\hline & \multicolumn{2}{c}{ Fitch } & \multicolumn{2}{c}{ Moody's } & \multicolumn{2}{c}{ S\&P } \\
& Coefficient & P-Value & Coefficient & P-Value & Coefficient & P-Value \\
\hline Rating & $-0.75^{* * *}$ & 0.00 & $-0.68^{* * *}$ & 0.00 & $-0.76^{* * *}$ & 0.00 \\
Constant & $15.41^{* * *}$ & 0.00 & $13.95^{* * *}$ & 0.00 & $15.41^{* * *}$ & 0.00 \\
& & & & & & \\
R-squared & 0.52 & & 0.54 & & 0.55 & \\
Observations & 165 & & 165 & & 165 & \\
\hline
\end{tabular}

This table presents the results of a bivariate regression of sovereign ratings on yield spreads. Panel-corrected standard error (PCSE) parameter estimates are used. p-values are reported next to the coefficients, asterisks indicate statistical significance $\left(* * * \mathrm{p}<0.01,{ }^{* *} \mathrm{p}<0.05,{ }^{*} \mathrm{p}<0.1\right)$.

\section{Table 5.1 Observed credit ratings: Effect on yield spreads}

But to what extent is this effect attributable to idiosyncratic opinion, rather than measurable fundamentals? Following the approach of Gärtner et al. (2011, pp. 295 ff.), this section proceeds by decomposing credit ratings into three components - one explained by fundamentals, one representing an unexplained markup on GIPS countries during crisis, and one representing other unexplained variation - and then tests each component's effect on yield spreads. Given a regression according to equation (4.3), credit ratings can be represented as

$$
R_{a, i, t}=\hat{R}_{a, i, t}^{X}+\hat{R}_{a, i, t}^{P * C}+\hat{\epsilon}_{a, i, t}
$$

Here, $R_{a, i, t}$ is the observed credit rating, $\hat{R}_{a, i, t}^{X}$ captures the part of credit ratings that is explained by economic and institutional fundamentals $\left(\hat{\alpha}+\hat{\beta}^{I} X_{i, t}+\hat{\delta} C R I S I S_{i, t}+\hat{\lambda} G I P S_{i, t}\right)$ and $\hat{R}_{a, i, t}^{P * C}$ reflects idiosyncratic treatment of GIPS countries during the crisis, i.e. a markup that is unexplained by measurable fundamentals, $\hat{\gamma}\left(G I P S_{i, t} * C R I S I S_{i, t}\right)$. $\hat{\epsilon}_{a, i, t}$ captures other unexplained factors that affected all countries alike, i.e. the regression residuals. To assess whether markets are affected by each component, specifically by the opinion of agencies, these components are then regressed on yield spreads, such that

$$
S_{i, t}=\eta \hat{R}_{a, i, t}^{X}+\theta \hat{R}_{a, i, t}^{P * C}+\kappa \hat{\epsilon}_{a, i, t}+\mu_{i, t}
$$

where $S_{i, t}$ denotes the spread of country $i$ 's bond yield at time $t$ to that of Germany.

Table 5.2 compares the results of a regression according to equation (5.2) across the three agencies in the odd-numbered columns. All components possess significant negative effects on yield spreads. Evidently, the impact of fundamentals is rather similar between the three agencies, with, ceteris paribus, 


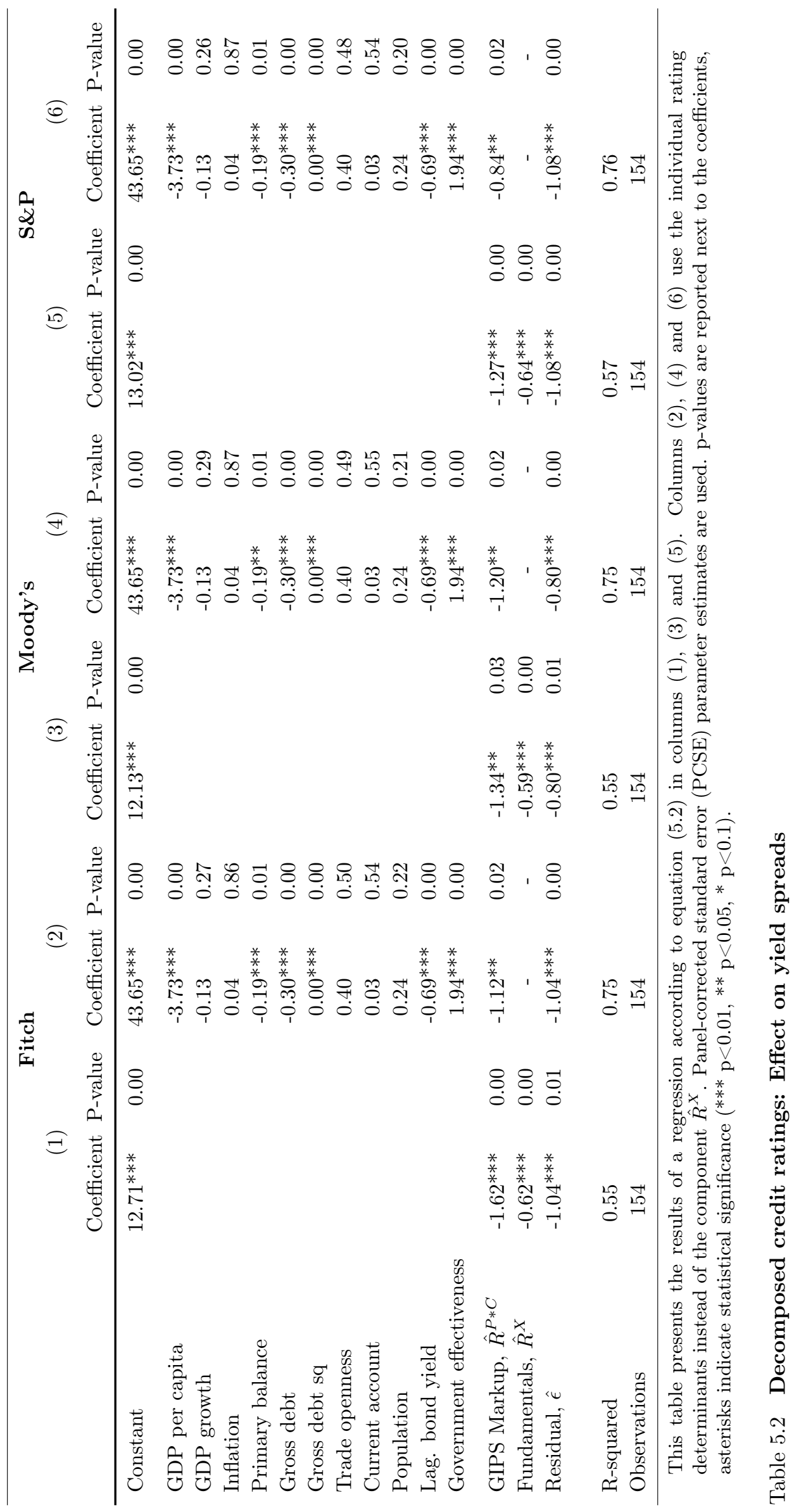


a negative effect of around 0.6 points decrease in the yield spread for a one notch improvement, i.e. increase in the rating. The markup has the strongest effect for ratings of Fitch and least strong for Moody's. Comparing the coefficients, markets appear to be affected by changes in the subjective component of ratings much more than by changes in agencies' assessment of measurable fundamentals. The effects are considerable. Given the 2.2 notch markup used by S\&P during the crisis, markets would demand a risk premium of almost 3 points during the crisis, ceteris paribus, on average between the GIPS.

The even-numbered columns use the individual regressors $X_{i, t}$ of equation (4.3) together with the markup. The results suggest that markets do not take all of the determinants of sovereign ratings into account, but rather a small subset of five variables: GDP per capita, primary balance, gross debt, avg. lagged bond yield and the effectiveness of governance. This is in slight contrast to Gärtner et al. (2011), who found only inflation and lagged bond yields to be significant in explaining sovereign yield spreads. While it is unclear what brought about these differences, it could be caused by the broader specification as well as by differences in the underlying data sources for both the dependent and the independent variable.

\section{Conclusion}

A number of observers voiced concern about the actions taken by rating agencies after the onset of the Euro crisis in 2009. In particular, the justification of the unusually frequent and oftentimes harsh downgrades of peripheral Eurozone countries has been called into question. In the eyes of many, GIPS countries were seen as victims of the agencies, suffering surges in yields as a result of excessive downgrades, which raised borrowing costs and thereby worsened the crisis.

The results of the econometric exercise in this paper support these critiques. Based on a structural model of rating determinants, significant evidence of a markup for GIPS countries during and before the Eurozone crisis is found. Although some agencies appeared to have employed such a markup more extensively during the crisis than before, the results suggest that GIPS countries were rated systematically lower unanimously by the Big Three. During the crisis, the markup is found to range from 1.5 rating notches for Moody's to 2.2 notches for S\&P. While S\&P's markup during the crisis was thus considerably larger than that of the other Big Three, Fitch and Moody's are found to have used an even stronger markup over the entire sampling period. This general GIPS markup was estimated at 1.5 and 1.3 notches, respectively, and insignificant for S\&P. Overall, GIPS countries were thus rated about 2.5 notches lower than other EMU members between 1999 and 2013, irrespective of economic or institutional fundamentals.

A subsequent decomposition of credit ratings into systemic and arbitrary components suggests that this markup - essentially reflecting the Big Three's opinion - had a significant effect of risk premiums during the crisis. On average, yield spreads of GIPS countries increased by between 1.27 points (S\&P) to 1.62 points (Fitch), ceteris paribus, per each one-notch increase in the markup. Given that billions of Euros in bonds are issued by individual countries each year, these numbers reflect considerable costs to GIPS countries that are attributable solely to the opinion of the Big Three. As a consequence, and bearing in mind that credit ratings are used for regulatory purposes, this suggests the need for close supervision. 


\section{References}

Afonso, A. (2003). Understanding the determinants of sovereign debt ratings: evidence for the two leading agencies. Journal of Economics and Finance, 27(1), 56-74.

Afonso, A., Furceri, D., \& Gomes, P. (2012). Sovereign credit ratings and financial markets linkages: application to European data. Journal of International Money and Finance, 31(3), 606-638.

Afonso, A., Gomes, P., \& Rother, P. (2007, January). What "hides" behind sovereign debt ratings. ECB Working Paper, (711), 1-67.

Alsakka, R. \& ap Gwilym, O. (2010). Leads and lags in sovereign credit ratings. Journal of Banking \& Finance, 34 (11), 2614-2626.

Bank for International Settlement. (2013, December). Low rates spur credit markets as banks lose ground. BIS Quarterly Review.

Beck, N. \& Katz, J. N. (1996). Nuisance vs. substance: specifying and estimating time-series-crosssection models. Political analysis, 6(1), 1-36.

Becker, B. (2011, June). Credit ratings - the problems with ratings, their role in the financial meltdown and their future. Financial Market Committee Report no 7, 1-28.

Biglaiser, G. \& Staats, J. L. (2012). Finding the "democratic advantage" in sovereign bond ratings: the importance of strong courts, property rights protection, and the rule of law. International Organization, 66(3), 515-535.

Brown, J. M. (2010, April 22). Ireland's budget deficit highest in EU. Financial Times. Retrieved April 16, 2014, from http://www.ft.com/cms/s/0/0b8dbb0e-4e1e-11df-b437-00144feab49a.html

Cantor, R. \& Packer, F. (1996). Determinants and impact of sovereign credit ratings. The Journal of Fixed Income, 6(3), 76-91.

Clark, E. A. \& Zenaidi, A. (1999). Sovereign debt discounts and the unwillingness to pay. Finance, 20(2), 185-199.

De Haan, J. \& Amtenbrink, F. (2011, January). Credit rating agencies. DNB Working Paper, (278).

Economic and Financial Committee. (2004). Status Report on Information Requirements in EMU. Brussels. Retrieved January 15, 2015, from https://www.ecb.europa.eu/stats/pdf/statusreportEMU. pdf

Fuchs, A. \& Gehring, K. (2013). The home bias in sovereign ratings. Discussion Paper Series / University of Heidelberg, Deparment of Economics, 0552(54). Retrieved from http://www.ub.uniheidelberg.de/archiv/16015

Fuchs, A. \& Gehring, K. (2014). Evidence and explanations for a home bias in sovereign ratings. Alfred-Weber-Institute for Economics, Heidelberg University. Retrieved February 11, 2012, from http://kai-gehring.net/

Gärtner, M., Griesbach, B., \& Jung, F. (2011). PIGS or lambs? the European sovereign debt crisis and the role of rating agencies. International Advances in Economic Research, 17(3), 288-299.

Herndon, T., Ash, M., \& Pollin, R. (2014). Does high public debt consistently stifle economic growth? a critique of reinhart and rogoff. Cambridge Journal of Economics, 38(2), 257-279. 
Kaufmann, D., Kraay, A., \& Mastruzzi, M. (2011, September). The Worldwide Governance Indicators: methodology and analytical issues. Hague Journal on the Rule of Law, 3(02), 220-246.

Mellios, C. \& Paget-Blanc, E. (2006). Which factors determine sovereign credit ratings? The European Journal of Finance, 12(4), 361-377.

Reinhart, C. M. \& Rogoff, K. S. (2010). Growth in a time of debt (digest summary). American Economic Review, $100(2), 573-578$.

White, L. J. (2010). Markets: The credit rating agencies. The Journal of Economic Perspectives, 24(2), $211-226$.

Wooldridge, J. M. (2010). Econometric analysis of cross section and panel data. Cambridge, MA: MIT Press.

\section{A Appendix}

\begin{tabular}{lll}
\hline Variable & Definition & Source \\
\hline GDP per capita & Log GDP per capita in constant 2005 EUR & AMECO \\
GDP growth & $\begin{array}{l}\text { Percent-change of real GDP in 2005 prices (annual \%). Three- } \\
\text { year average }\end{array}$ & AMECO \\
Inflation & Consumer price inflation (annual \%). Three-year average & OECD \\
Gross debt & $\begin{array}{l}\text { Real general government gross consolidated debt based on } \\
\text { ESA95. Measured in constant 2005 EUR as percentage of GDP }\end{array}$ & EFA, table 57B \\
Primary balance & $\begin{array}{l}\text { Net lending }(+) \text { or net borrowing (-) excluding interest on gen- } \\
\text { eral government level, based on ESA95. Measured in constant }\end{array}$ & EFA, table 55B \\
& $\begin{array}{l}\text { 2005 EUR as percentage of GDP. Three-year average } \\
\text { Trade openness }\end{array}$ & AMECO \\
Turrent account balance & $\begin{array}{l}\text { Balance on current transactions with the rest of the world, } \\
\text { measured in constant 2005 EUR. Three-year average }\end{array}$ & WDI \\
Population & $\begin{array}{l}\text { Log total population } \\
\text { Bond yield }\end{array}$ & AMECO \\
Government effectiveness & $\begin{array}{l}\text { Index ranging from }-2.5 \text { (worst) to }+2.5 \text { (best). Due to the } \\
\text { biyearly measurement of WGI before 2002, two missing data }\end{array}$ & WGI \\
& points are interpolated using cubic splines, in 1999 and 2001. & \\
\hline
\end{tabular}

This table depicts variables, definitions and sources of independent variables. AMECO refers to the Annual MacroEconomic Database (AMECO) of the European Commission for Economic and Financial Affairs, OECD to the organization's statistical database, EFA to the European Commission Directorate General Economic and Financial Affairs Autumn 2013 report General Government Data, WDI to the Word Development Indicators 2013 of the World Bank and WGI to the Worldwide Governance Indicators dataset of Kaufmann, Kraay, and Mastruzzi (2011), maintained by and available through the World Bank. Three-year averages are used for short-term indicators, adopted from Fuchs and Gehring (2013) as well as rating agencies' self-stated disregard for short-term fluctuations. In 2010, for example, S\&P reacted to a sharp adjustment in Ireland's budget deficit by stating that it "did not affect our view of the underlying position of the Irish public finances" (Brown, 2010). Natural logarithms are used to remove time trends. Due to biyearly measurement of WGI before 2002, two data points had to be interpolated using cubic splines, in 1999 and 2001.

Table A.1 Variables, definitions and sources 
France

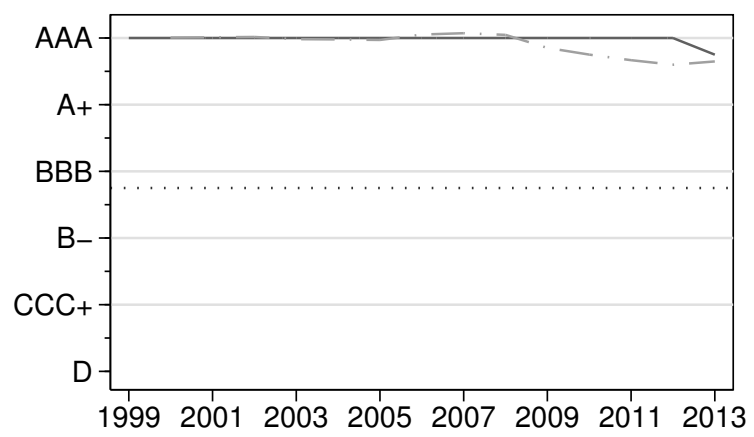

Italy

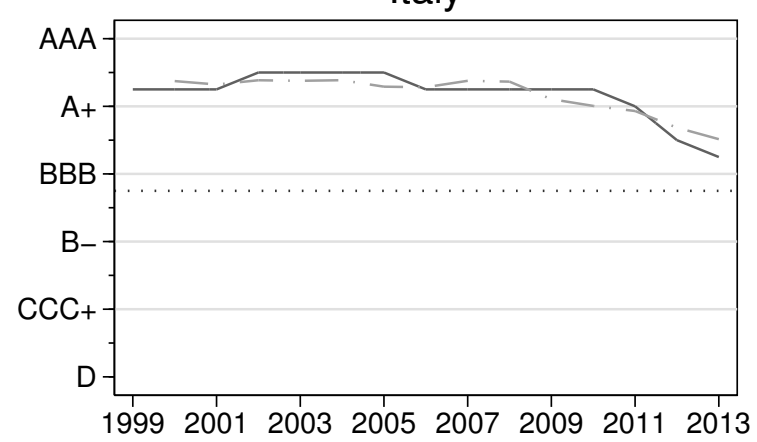

Greece

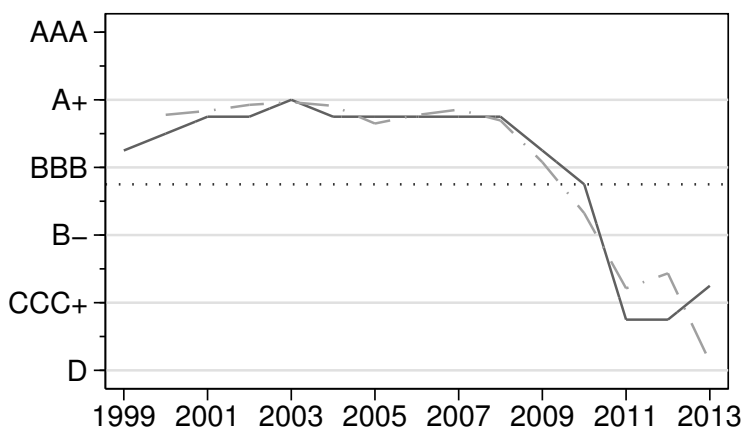

Portugal

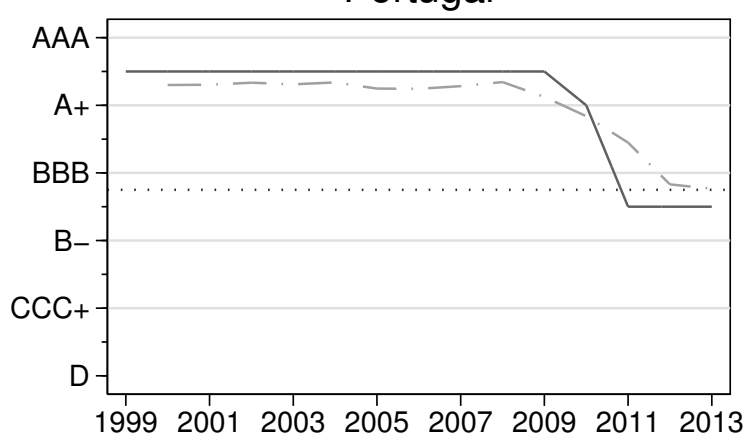

Germany

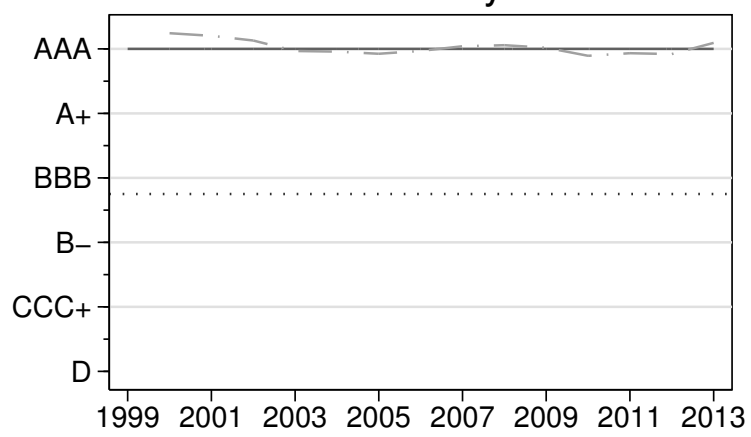

Netherlands

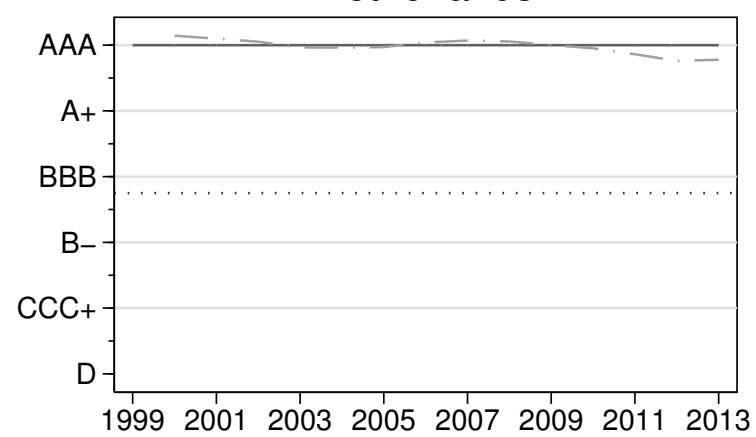

Ireland

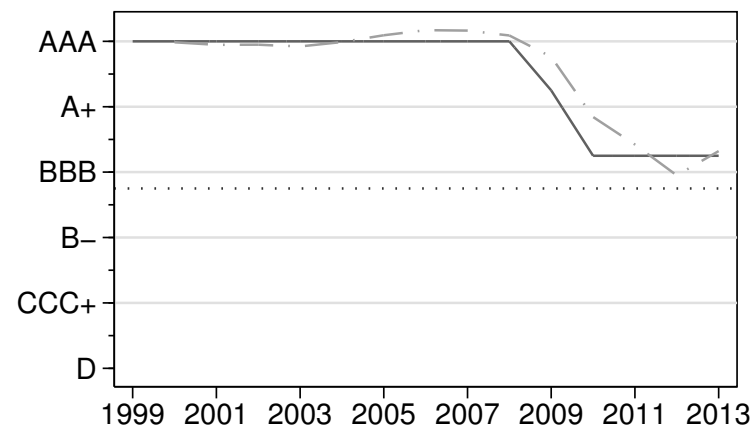

Spain

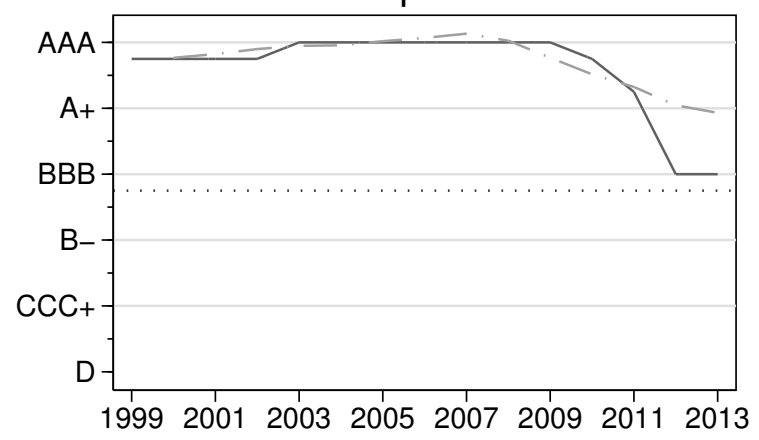

Figure A.1 Prediction (dashed line) and actual ratings (solid line) for Fitch 


\section{France}

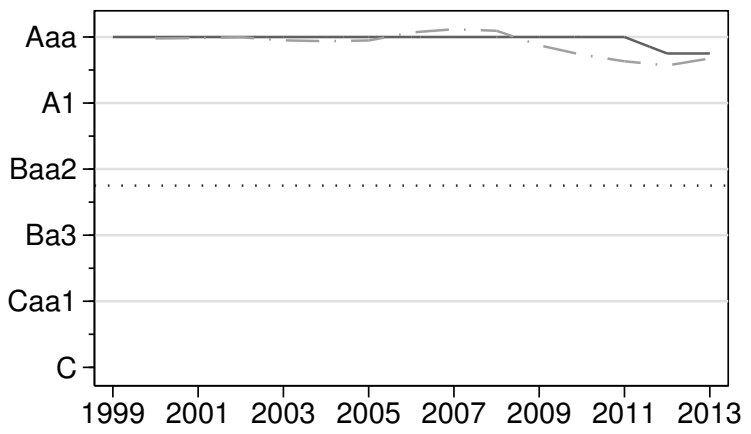

Italy

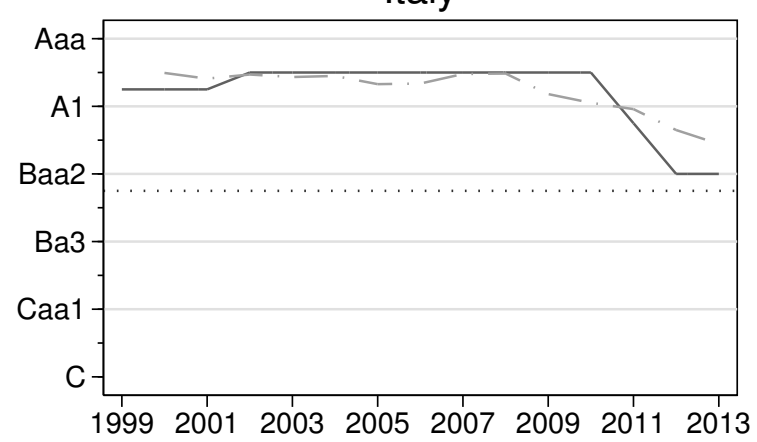

Greece

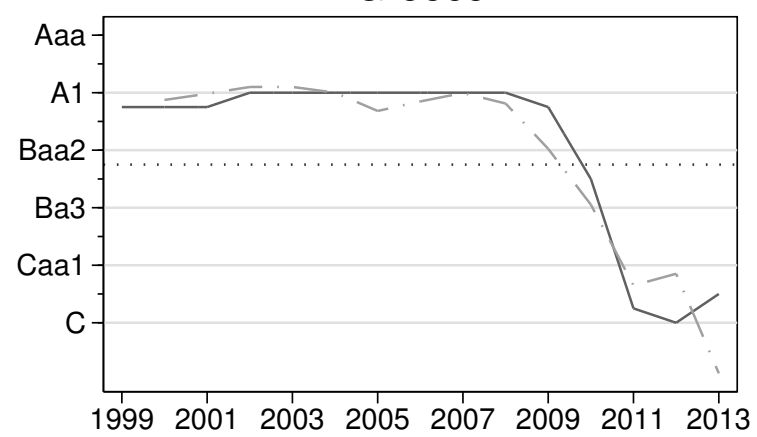

Portugal

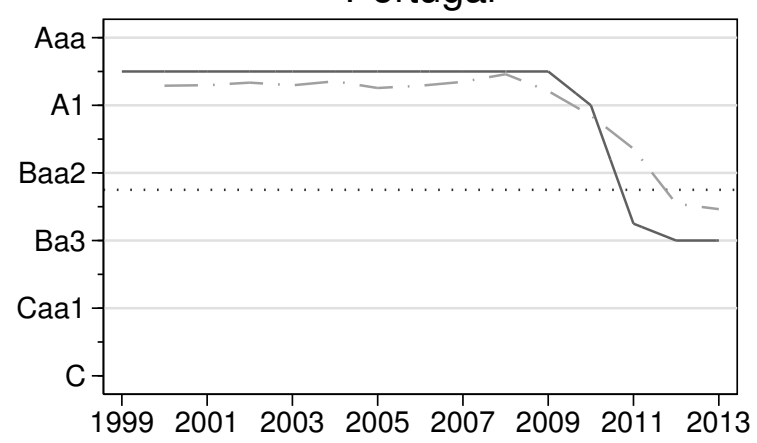

Germany

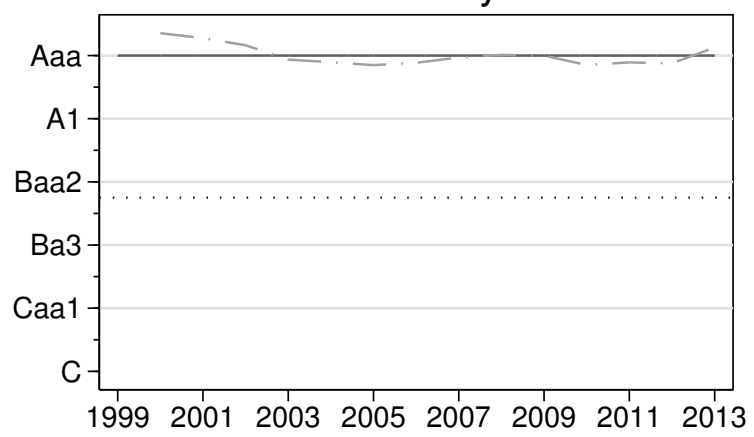

Netherlands

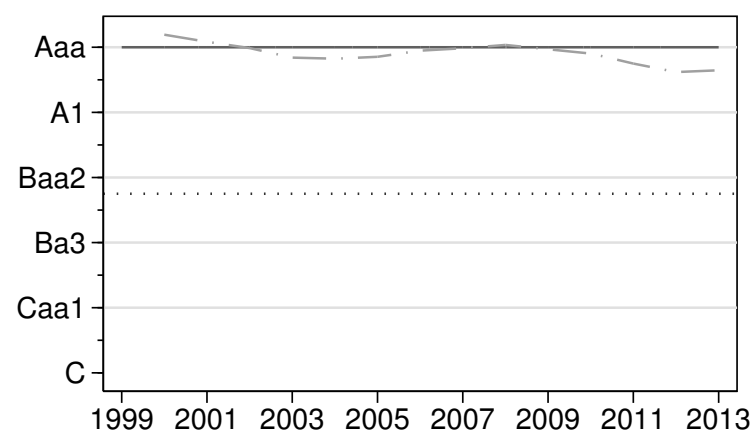

Ireland

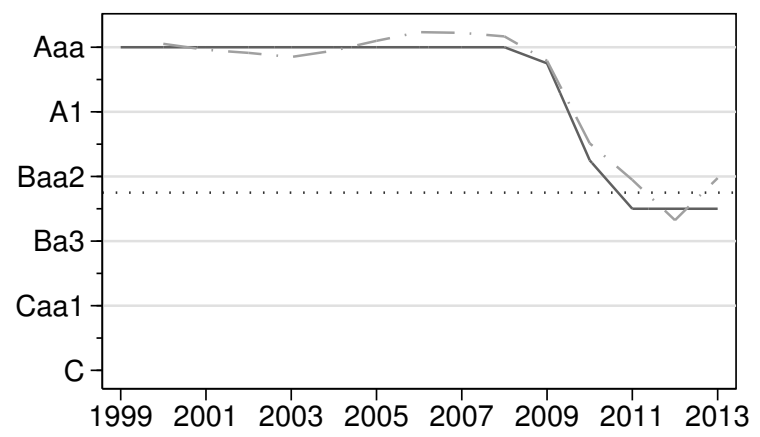

Spain

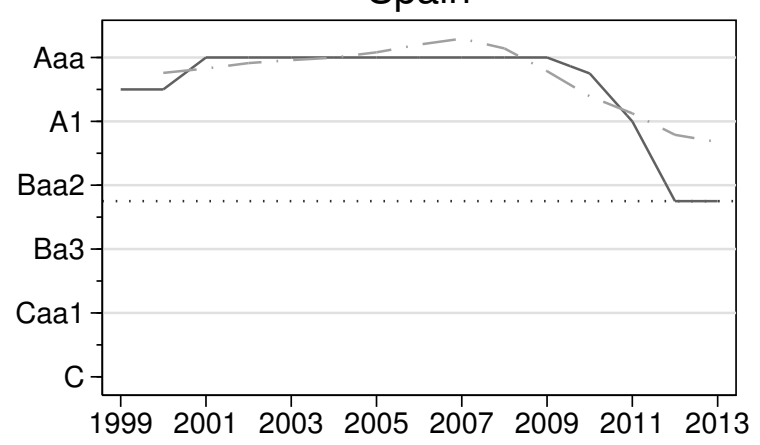

Figure A.2 Prediction (dashed line) and actual ratings (solid line) for Moody's 
France

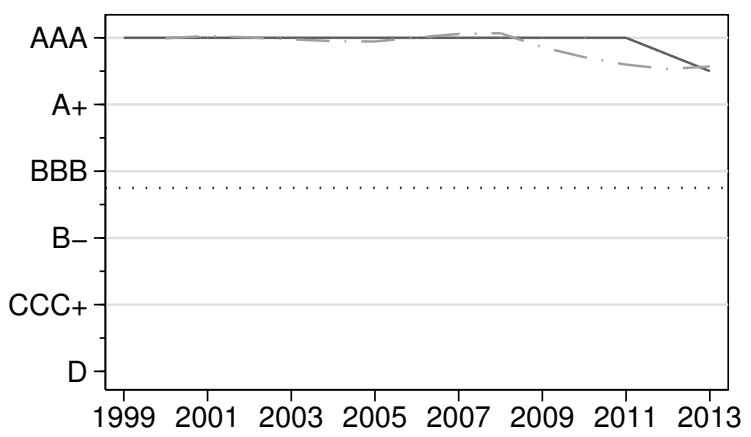

Italy

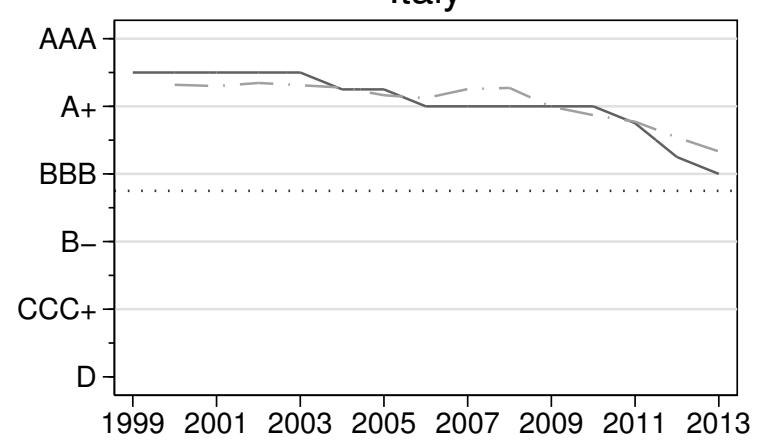

Greece

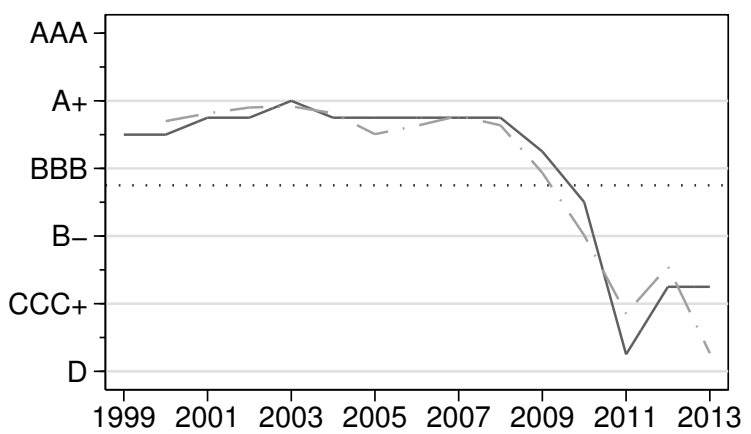

Portugal

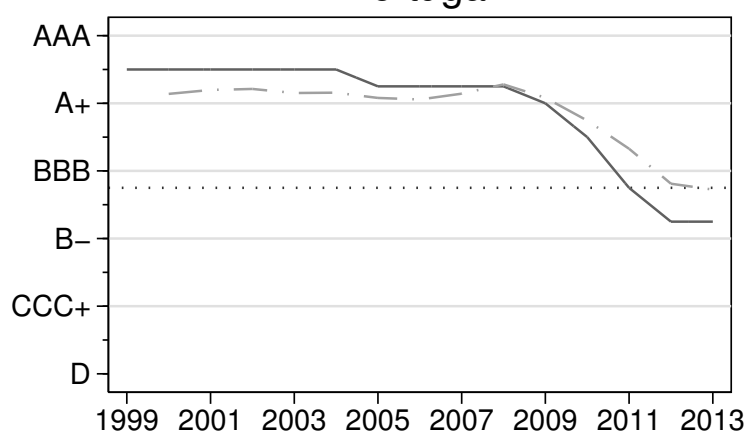

Germany

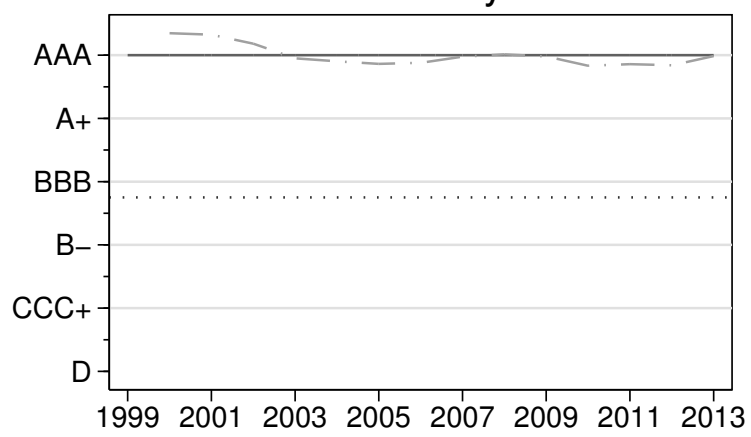

Netherlands

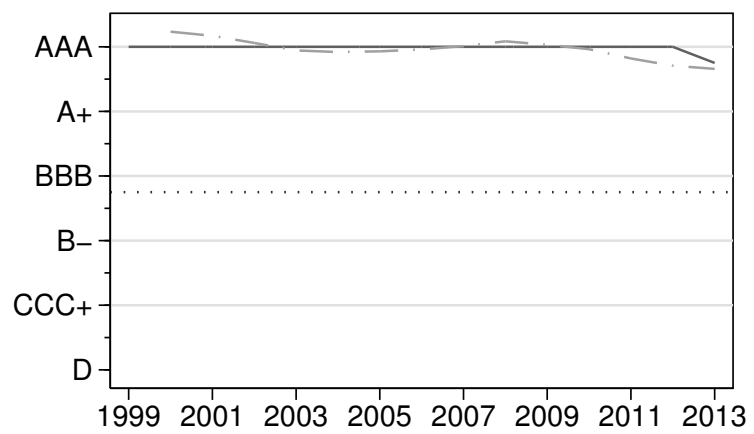

Ireland

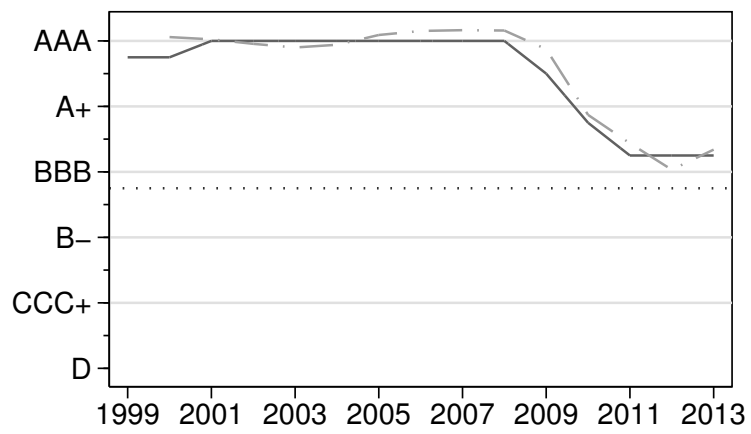

Spain

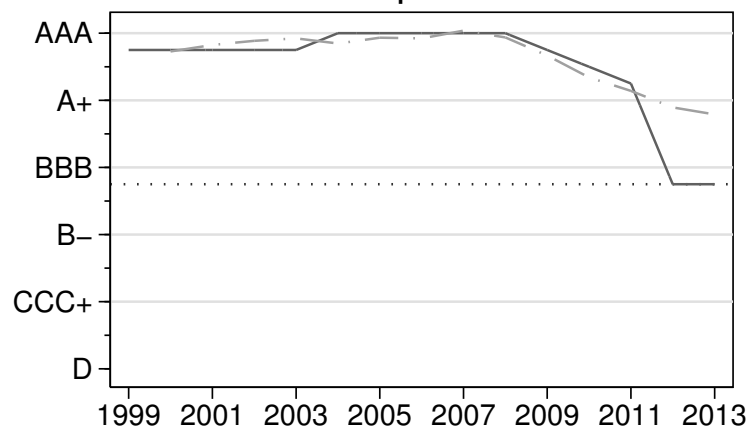

Figure A.3 Prediction (dashed line) and actual ratings (solid line) for S\&P 


\begin{tabular}{|c|c|c|c|c|c|c|}
\hline & \multicolumn{2}{|c|}{ Fitch } & \multicolumn{2}{|c|}{ Moody's } & \multicolumn{2}{|c|}{$\mathbf{S \& P}$} \\
\hline & Coefficient & P-Value & Coefficient & P-Value & Coefficient & P-Value \\
\hline GDP per capita & 4.40 & 0.45 & $16.09^{*}$ & 0.08 & $18.25^{* *}$ & 0.04 \\
\hline GDP growth & 0.44 & 0.49 & -0.32 & 0.59 & $-0.56^{* *}$ & 0.02 \\
\hline Inflation & -0.28 & 0.79 & $-1.34^{* *}$ & 0.05 & -1.38 & 0.34 \\
\hline Gross debt & -0.33 & 0.16 & $-0.34^{* * *}$ & 0.00 & $-0.29 *$ & 0.05 \\
\hline Gross debt sq & 0.00 & 0.54 & 0.00 & 0.18 & 0.00 & 0.70 \\
\hline Primary balance & 0.02 & 0.92 & $0.74^{* *}$ & 0.03 & $0.69^{* * *}$ & 0.01 \\
\hline Trade openness & -1.67 & 0.50 & -5.82 & 0.24 & 1.95 & 0.67 \\
\hline Current account & $-0.34^{*}$ & 0.06 & $-0.48^{* * *}$ & 0.00 & $-0.78 * * *$ & 0.00 \\
\hline Population & -0.13 & 0.93 & -0.80 & 0.61 & $4.18^{* *}$ & 0.02 \\
\hline Lag. bond yield & 0.03 & 0.87 & -0.03 & 0.86 & $0.36^{*}$ & 0.08 \\
\hline Government effectiveness & 2.40 & 0.31 & $2.85^{* * *}$ & 0.01 & $7.60^{*}$ & 0.05 \\
\hline Crisis & 1.92 & 0.16 & -0.38 & 0.49 & $-1.39 * *$ & 0.02 \\
\hline GIPS & $-8.46^{* * *}$ & 0.00 & $-5.90^{*}$ & 0.08 & -4.23 & 0.20 \\
\hline GIPS*Crisis & -1.59 & 0.11 & 0.56 & 0.52 & $-2.09^{*}$ & 0.06 \\
\hline Cut-off 1 & -2.04 & 0.97 & 95.34 & 0.21 & $209.88^{* *}$ & 0.04 \\
\hline Cut-off 2 & 0.03 & 1.00 & 96.19 & 0.20 & $213.54^{* *}$ & 0.04 \\
\hline Cut-off 3 & 4.58 & 0.94 & 97.20 & 0.20 & $215.87^{* *}$ & 0.03 \\
\hline Cut-off 4 & 5.54 & 0.93 & 99.64 & 0.19 & $218.01^{* *}$ & 0.03 \\
\hline Cut-off 5 & 6.95 & 0.91 & 100.51 & 0.18 & $221.80^{* *}$ & 0.03 \\
\hline Cut-off 6 & 9.49 & 0.87 & 104.16 & 0.16 & $222.21^{* *}$ & 0.03 \\
\hline Cut-off 7 & 10.16 & 0.87 & 106.02 & 0.15 & $224.70^{* *}$ & 0.03 \\
\hline Cut-off 8 & 12.37 & 0.83 & 107.14 & 0.15 & $225.83^{* *}$ & 0.03 \\
\hline Cut-off 9 & 13.61 & 0.82 & 107.54 & 0.15 & $229.42^{* *}$ & 0.03 \\
\hline Cut-off 10 & 16.14 & 0.79 & 108.92 & 0.14 & $231.61^{* *}$ & 0.03 \\
\hline Cut-off 11 & 19.86 & 0.74 & 111.72 & 0.13 & $233.89^{* *}$ & 0.03 \\
\hline Cut-off 12 & 22.13 & 0.71 & 112.87 & 0.13 & $240.60^{* *}$ & 0.02 \\
\hline Cut-off 13 & & & 116.72 & 0.12 & $246.81^{* *}$ & 0.02 \\
\hline Cut-off 14 & & & 120.66 & 0.11 & & \\
\hline$\sigma_{u}^{2}$ & 0.00 & 0.95 & 3.25 & 0.50 & 8.48 & 0.40 \\
\hline Pseudo R-squared & 0.55 & & 0.55 & & 0.59 & \\
\hline Observations & 154 & & 154 & & 154 & \\
\hline
\end{tabular}

This table presents the results of a random-effects ordered logit regression of rating determinants and dummy variables on credit ratings for Fitch, Moody's and S\&P. In contrast to table 4.3, this table depicts the cut-off points, allowing for an interpretation of the marginal effects beyond at-means. Standard errors are clustered on country level. p-values are reported next to the coefficients, asterisks indicate statistical significance $\left({ }^{* * *} \mathrm{p}<0.01,{ }^{* *} \mathrm{p}<0.05,{ }^{*} \mathrm{p}<0.1\right)$.

\section{Table A.2 Results of ordered-logit regression with cut-off points}

